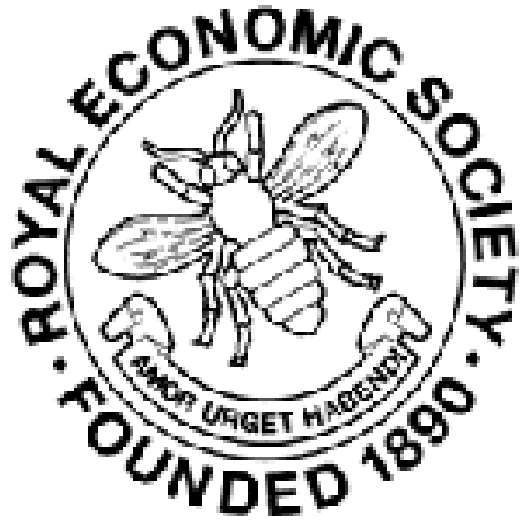

Local Control and the Income Tax

Author(s): W. B. Cowcher

Source: The Economic Journal, Vol. 21, No. 82 (Jun., 1911), pp. 285-291

Published by: Wiley on behalf of the Royal Economic Society

Stable URL: http://www.jstor.org/stable/2222381

Accessed: 27-06-2016 08:12 UTC

Your use of the JSTOR archive indicates your acceptance of the Terms \& Conditions of Use, available at

http://about.jstor.org/terms

JSTOR is a not-for-profit service that helps scholars, researchers, and students discover, use, and build upon a wide range of content in a trusted digital archive. We use information technology and tools to increase productivity and facilitate new forms of scholarship. For more information about JSTOR, please contact support@jstor.org.

Royal Economic Society, Wiley are collaborating with JSTOR to digitize, preserve and extend access to The Economic Journal 
eventually within the year the people of Canada will have an opportunity to pass judgment upon it at the polls.

O. D. Skelton.

\section{Local Control and the Income Tax.}

Two recent enactments in connection with the Income Tax are worthy of remark in so far as they indicate something in the nature of a departure from or variation of the original plan upon which our Income Tax practice is based.

Under the Finance Act of 1909-10, the administration of the Supertax part of the Income Tax, that is, the special tax upon aggregate incomes exceeding $£ 5,000$ per annum, is vested in the Special Commissioners, and is for most practical purposes, controlled by the Board of Inland Revenue. Under Section 69 of the same Act, the Local Surveyor of Taxes is authorised to grant certificates of repayment in respect of the additional allowances for repairs of cottages and lands. Provided that he considers the claim to be satisfactory, he need not invoke the aid of the District Commissioners. In other words, the latter are only to deal with contentious cases.

It must, however, be admitted that the practice, to which legal sanction is here given, is one that has been in general vogue for many years. Under the fundamental Act of 1842, even as amended by subsequent enactments, the District Commissioners, in all cases not falling within the purview of the Special Commissioners, were made supreme. With few exceptions, every error, however palpable, every rectification, however simple and obvious, has to be dealt with by personal appeal before the Commissioners. It does not matter in the slightest whether or not the Crown and the Taxpayer are agreed upon the point at issue. The sole procedure is as stated.

This, of course, was carrying local control to an extreme limit, and, as might be expected, the Commissioners' rôle in undisputed adjustments, is usually little more than a formal blessing upon the settlements arrived at. Section 69 of the Act of 1909-10, merely gives legal sanction to a practice that experience has shown would be the inevitable outcome.

Still, history shows there to be an ever-increasing tendency towards the centralisation of authority, and as I conceive the part played by the District Commissioners to be the most valuable and unique feature in the Income Tax administration, it may serve a useful purpose to explain more or less precisely their position. 
Who, then, are these local Commissioners? How are they appointed? And what are their qualifications? The General Commissioners of the Income Tax, to give them their correct title, are an offshoot from the Commissioners of the Land Tax. The latter comprises all the local magistracy and certain other gentlemen who are included in the "Name Acts." In a word, the honour of a Land Tax Commissionership, with its nominal duties, is usually, but not always, the reward of minor political services. There is now no property qualification for the post, and like the Income Tax Commissionership it is honorary in character.

The Land Tax Commissioners appoint the General Commissioners of the Income Tax from those among their number possessing the necessary property qualification. This latter contains many variations of little practical importance, but may be said to embrace the sound maxim that the control of the Income Tax shall be in the hands of those who pay it. Apart from this, the General Commissioners need have no special fitness for the task imposed upon them.

In their turn the General Commissioners give birth to what are known as the "Additional Commissioners." These are either a committee of the General Commissioners themselves, or are taken from the list to supply vacancies amongst the General Commissioners. To them is entrusted the work of making all the assessments upon trades and professions under Schedule D, in all cases where choice or the law does not call for the service of the Special Commissioners. (The latter are paid officials appointed by the Treasury.)

It is to be noted, however, that in the case of a General Commissioner having acted as an Additional Commissioner, he is thereby precluded from hearing appeals against assessments made by him in the latter capacity.

In actual practice, the constitution of the General or District Commissioners is extremely varied in type. In the country districts, the boards are usually composed of the "nobility, gentry, and clergy," the same class, often the same individuals, as is met with upon the county bench. In most of the towns, the preference seems to be for retired business men, whilst in some of the largest centres it seems to be for the higher grade of merchants and manufacturers. Speaking generally, the choice falls upon persons who have the reputation for financial stability and sound judgment. The wisdom with which the choice is usually made, is reflected in the small proportion of those who 
elect to be assessed by the Special Commissioners rather than disclose their private business to the local body. In this connection, there is, however, a modern tendency towards assessment by the Special Commissioners in the cases where the framing of the taxpayers' returns is entrusted to professional accountants.

Such, then, is the nature of the authority upon which rests the burden of controlling the English Income Tax-"an unpaid committee of amateur tax-lawyers," as I have known them to be characterised.

Nevertheless, I have not the slightest hesitation in saying that it has been very largely due to this body that the tax has remained in continuous operation since 1842. A centralised administration would have relegated it to oblivion for the greater part of the time.

What, then, is the great feature embodied in the method employed? To what is it due that the administration has become probably the most efficient and certainly the least bureaucratic of any in the world?

One of the most extraordinary features of the system is, the smallness of the powers conferred upon the representatives of the Crown. Almost everywhere in the Acts we read of things to be done by the General Commissioners. Rarely is the Surveyor mentioned at all. And yet, if the average income taxpayer were asked who was the most important local income tax official, the odds are that he would at once mention the Surveyor of Taxes.

$\mathrm{He}$ would be, from his point of view, undoubtedly quite right. The Surveyor is the person to whom he would go with his complaints; and it is possible for a man to go through a long business career as a regular taxpayer without ever knowing that the court of the Commissioners is anything more than a departmental "Mrs. Harris."

The position is one of those curious examples of English selfgovernment under which the powers assigned to one authority are, in practice, largely exercised by another. Still, large as is the part taken by the Surveyor, as the representative of the Crown, in the actual levying of the tax, there is little doubt but that the secret of its success lies in the system of joint control under which the local and central authorities work together, and for the most part in complete harmony.

When Peel introduced his Income Tax Bill in 1842 it met, as might be expected, with very great opposition. The only people who are as a class enamoured of the tax are those whose incomes are too small for its purview. Inquisitorial by nature, 
without the sugar-coating of an indirect tax, no statesman is likely to introduce such a tax for revenue purposes except in a time of emergency.

The only way to make the dose less unpalatable, and at the same time to take hostages for its future permanence, was to admit the principle of local control, with its attendant patronage, to the fullest extent. The effect of the Act of 1842 is very much as if the Premier had said, "I must have an income tax, but I will let the people assess themselves and collect the money themselves through local bodies over which the central Government shall have no control whatever apart from a general supervision by its local representative. This, of course, will be necessary in order to secure uniformity and prevent evasion. The power of the Crown shall be limited to cases where there is a default in the carrying out of the Act, or where the taxpayer, under Schedule D, prefers to avoid local disclosure of his finances. Nothing shall be done to impair the absolute and final supremacy of the Commissioners in all questions of fact." This supremacy is the keynote of the whole business.

It must not be thought, however, that the whole of the work, and the success that has attended it, is due to the local Commissioners. As bodies they present manifold degrees of activity and efficiency. In some districts they personally discharge the whole of the duties assigned to them, and in those districts the position of the Crown official is one of decidedly inferior importance. In others their share of the work is little more than the formal blessing attested by their signatures. In such districts the Surveyor of Taxes, if he is a person of capacity, is apparently supreme.

I say apparently because such is far from being the real position. The powers conferred upon the Commissioners by law, albeit apparently dormant, are in reality in active operation below the surface.

It is not my intention to show why bureaucracies tend to become arbitrary and unjust. But it is generally agreed that they do, and in few domains is there so great a possibility for this development as in the income tax administration. What, then, is the reason why there is such a small amount of this evil even where, as frequently happens in unimportant centres, the whole of the control seems to have been abdicated by the Commissioners to the Surveyor.

The answer lies in the fact that the Commissioners generally, and the Surveyor always, know that whatever discretionary powers the latter exercises can only be exercised so long as he 
retains the confidence of the body in whom the powers are legally vested. A Surveyor who should fail in this all-important respect would find himself in an utterly untenable position. He would be reduced almost to impotence, and it would not be long before he would be transferred elsewhere.

It is a tribute to the English capacity for self-government that these circumstances rarely arise in practice. Local Commissioners, Commissioners of Inland Revenue, and the local Surveyor of Taxes work in harmony together. What is more, it may be hazarded as an independent opinion that each of these powers tends to correct the untoward tendencies of the remainder.

The local Commissioners have a wholesome respect for the criticism that is inherent in the presence of the Crown official. The latter's undue exercise of authority is effectually thwarted by the Commissioners' supremacy in disputed cases. The possible development of undue technicality through the central authority is corrected by the non-technical character of the Commissioners as an appellate body, and by the fact that the Board of Inland Revenue have, apparently, no right of direct representation at appeals. The overawing of the appellate body is impossible where the central power is filtered through subordinate officials. Finally, the Board of Inland Revenue have had the wisdom to recognise the virtues of the situation. They have always been glad to cast the onus of responsibility from their own shoulders on to the shoulders of the local Commissioners, thus at once adding to the importance of the latter and relieving themselves of odium.

The system I have outlined with its system of checks is unique in character, and has achieved the unstinted praise of foreign critics. But it goes without saying that, like everything else, it has its defects.

Three classes of objection have been put forward.

It is obvious that the success of the method is dependent upon the successful co-operation of the various authorities. Everything rests upon the honesty of purpose of the Local Commissioners. If the latter from any motive should become hostile and obstructive, they can offer almost insuperable obstacles to the proper assessment of the tax. The safeguards against evasion and unjust assessment are inseparably bound up with the uprightness of the local Commissioners. The fact that this aspect of the case has not assumed dangerous importance is a striking testimony to the common honesty of English public life. 
The second objection is that amateur bodies are, as a rule, manifestly unfitted to decide the nice questions of legal technicality that arise in the taxation under Schedule D. As, however, the taxpayer can appeal from an assessment under this schedule to the Special Commissioners, that is to say, he can choose the tribunal by which his case is to be heard, the objection is of little practical importance. The great body of the appeals is far better dealt with by the lay body. The latter is apt to decide cases upon broad, common-sense views in which its own local knowledge has been a principal factor. The work of such a tribunal makes for economy and precludes delay.

The third objection is a more serious one. Under the Act of 1842 , not only were the Commissioners empowered to appoint the assessors and collectors, make the assessments, and hear the appeals, but, through their clerk, they were also entrusted with the larger part of the routine clerical work involved in the preparation of the assessments. The remainder of this class of work devolves upon the Surveyor. I have no hesitation in saying that from an administrative point of view this is the most serious flaw in the Act. The very virtues of the system become its defects in dealing with this part of the work. The routine work of a bureaucracy is, as a rule, infinitely superior in precision and accuracy to that of a small local authority, especially where that local authority is, like the kind under review, absolutely irresponsible.

Under the Acts, I know of no security whatever for the clerical work entrusted to the Commissioners being promptly and properly done. Provided that they are prepared to certify that their clerk has done the work properly and to their satisfaction, there appears to be no right whatever upon the part of the Crown to withhold payment of the remuneration fixed by law, despite the fact that the Commissioners' certificate may be in striking contradiction to the real facts of the case. This flaw in the system has had, and is having, bad effects in many parts of the country. It is an evil that must inevitably increase with the complexity of the tax.

It must not, however, be thought that blame attaches to the clerks as a whole. Many of them do their work admirably. It is the system that is at fault. The routine work to be done is of the most dry-as-dust type. There is much of it, and it calls for close supervision. The great majority of the clerks do their best; but the absence of effective checking, and the incapacity for rapid expansion and contraction of the staff inevitable in small 
isolated offices, result in much of the work being ill-done and delayed. The attendant results are a heavy burden on the office of the local Surveyor, whose staff has to make good all deficiencies. There is not the slightest doubt but that, if the tax machinery were being set up afresh, in the light of past experience, no part of the clerical and statistical work would be entrusted to the local bodies. If at any future time the machinery of the tax is overhauled, this defect is the one that calls most insistently for remedy. Incidentally, it may be said that, owing to the vested interests involved, it is the one that is the least likely to get it.

In conclusion, it may be said that, notwithstanding the objections and defects mentioned, the position held by the local Commissioners to-day is a striking testimony to the wisdom of their creators. To entrust an income tax to almost unfettered local control was an act of extreme political daring. The result has shown that the boldest course is often the best.

W. B. CowCHER

\section{AgRICULTURAL EdUCATION.}

\section{Report of a Deputation from the University College, Reading, to Canada and the United States.}

WIтH the object of gaining information that might be useful in developing the work of the Agricultural Department of the above College, five members of the Council and Staff spent a month last year in visiting selected educational centres in North America. Their impressions and conclusions have been published by the College in a Report that is worth careful study. The scale on which agricultural education is undertaken in Canada and the States, makes our modest efforts in this country pale into insignificance. While the greatest of our achievements scarcely reaches a capital expenditure on buildings and equipment of $£ 20,000$, we find a single institution in Canada-the Macdonald College-supported to the extent of nearly a million sterling. A Department of Agriculture in an English University is thought to be well supported with $£ 2,000$ a year from public funds, which compares with $£ 25,000$ a year provided by the Government of Ontario for the maintenance of the Agricultural College at Guelph, and with double this amount in the case of the College of Agriculture at Cornell. Similar comparisons, not flattering to our position, may be instituted in regard to the number of students and the strength of the Staff. Such reflections make thinking people restless, and perhaps restlessness 